高齢者大腸癌切除例の臨床病理学的特徵とその遠隔成績 一若・壮年者大腸癌症例との比較を中心に一

\begin{tabular}{|c|c|c|c|c|c|c|c|c|c|c|c|c|}
\hline & & & & & 平场 & 市。 & 院夕 & 卜科 & & & & \\
\hline 井 & 洋 & 一 & 青 & 木 & 明 & 人 & 岡 & 芹 & 繁 & 夫 & 金 & 井 \\
\hline 田 & 英 & 雄 & 砂 & 長 & 貴 & 子 & 才 & $\mu$ & 義 & 朗 & 中 & 山 \\
\hline
\end{tabular}

大腸癌切除症例の5ち，75歳以上の高龄者61例につき，49歳以下の若・壮年者57例之 比較し，臨床病理学的所見および遠隔成績を検討した．切除率，治痹切除率および直接 死亡率に有意差を認めず，病变占居部位は，右側結腸が全体の $21.3 \%$ 之有意に多かった。 遠隔転移には両群に有意差を認めなかったが，リンパ節転移陰性例は高齢者群で $68.4 \%$ と若・壮年者群の $47.4 \%$ に比較し有意に多かった，病期では，高齢者群で Astler-Coller A の症例が $18.0 \%$ と有意に多く，遠隔転移やリンバ節転移のないAstler-Coller $\mathrm{B}_{2}$ をで の症例が $64.0 \%$ と有意に多かった．組織型では，分化型腺癌が全体の $95.0 \%$ と有意に多 く，若・壮年者群で，粘液癌が $12.3 \%$ と高龄者群の $1.6 \%$ に比較して有意に多かった。壁 深達度でも高龄者群で pm までの症例が37.8\% と若・壮年者群で14.1\%に比較し有意に 多かった。他病死を含めた累積 7 年生存率は, 高齢者群, 若・壮年者群でそれぞれ $22.3 \%$, $60.2 \%$ と若・壮年者群で有意に良好であったが，他病死を除いた 7 生率で，それぞれ $68.5 \%, 81.6 \%$ でり，両群に有意差を認めなかった。

真引用語：高齢者大腸癌

はじめに

近年, 大腸癌症例の増加と高齢化社会に伴って, 高 龄者の大腸癌症例に遭遇する機会が増えてきて拈り, 次第に症例が蓄積されている. 当院における大腸癌手 術症例”。, 近年増加しているのみならず, その中での 高龄者大腸癌の占める割合が明らかに増加してきてい る. 第27回大腸癌研究会では, 75歳以上の高齢者大腸 癌が主題にとりあげられ，その臨床的特徵が報告され

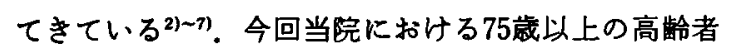
大腸癌症例の臨床病理学的成績とさらにその遠隔成績 を49歳以下の若・壮年者症例と比較検討するととるに, その問題点について考察を加えた。

\section{対象わよひ方法}

1970年 8 月より1989年 7 月までの過去 19 年間に，平 塚市民病院外科において取り报った大腸癌症例は，375 例で，そのうち，原発巣切除が行われたのは327例ある。 これら大腸癌切除症例の中で, 75歳以上のいわゆる高 龄者大腸癌は, 61例あり,これらの症例を高秢者群 $(\mathrm{H}$

1989 年10月19日受付 1990 年 4 月 24 日採用
群）として，検討の対象とした。これは切除症例の $18.7 \%$ に相当する.さらに，高龄者大腸癌の特徽を明 らかにするため, 同期間に切除された 49 歳以下の症例 57例を若・壮年者群 (LM 群) として高龄者群 (H 群) と比較検討した。

なお，病変の占居部位，壁深達度およびリンバ節轱 移などの臨床病理学的所見は, 大腸癌取扱い規約胀に 従った。病期分類には, Astler-Coller 分類9を用いた。 また，遠隔成樍の険討は，Kaplan-Meier 法 ${ }^{101}$ に従い生 存曲線を作成した。なお，発生頻度の推計学的有意差 検定は， $\chi^{2}$ 検定(必要に応してYates の修正を加えた) または Fisher の直接確率計算法で行った。生存率の有 意差検定には，generalized Wilcoxon 法を用いた。

\section{成 績}

\section{1）大腸癌切除例の年齢分布}

大腸癌切除例327例の年龄分布を図 1 に示した。年齢 は27〜89歳で，平均年龄は78.9歳で，65歳から69歳に ピークを有していた。その年齢構成は，年次別にみる と，年々高路化の傾向を示しており，1985年から1989 年の手術症例では，75歳以上の高齢者は，時期により 


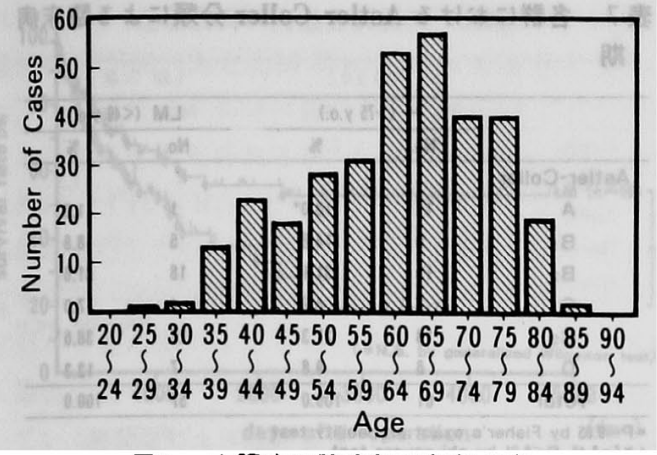

図 1 大腹癌切除症例の年柃分布

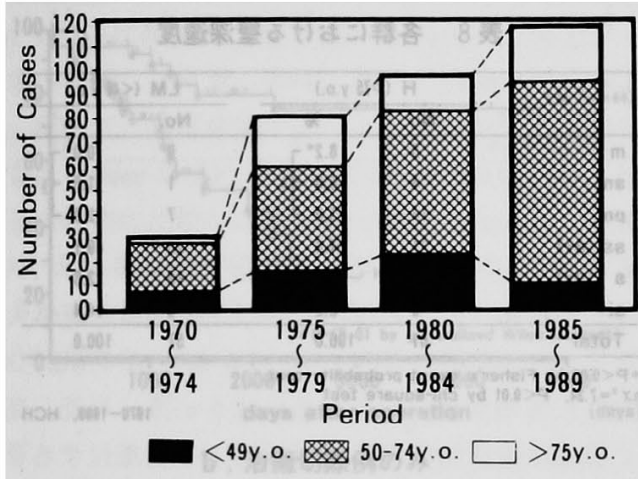

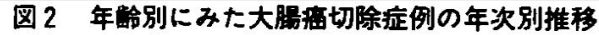

有意差は認めないものの，19.5\%を占めた(図 2 ). 一 方，49歳以下の若・壮年者は9.3\%と50歳以上の症例が 大部分を占め，1970１974年の手術症例に比し， 1985 1989年の症例が有意に $\left(x^{2}=3.18, p<0.05\right) 50$ 歳以上の症例が多かった。

\section{2) 性別}

性別につき，高龄者拈よび若・壮年者を比較した（表 1). 壮年者群で, やや女性に多い傾向を示したが, 高 齡者では，男女ほぼ同数であり，両群間に有意差を認 めなかった。

\section{3）病変占居部位}

両群において，それぞれ占居部位が結腸，直腸の頻 度を表 2 に示したが, 推計学的に有意差を認めなかっ た。一方，上行結腸に病変を有する症例が， H群で 16.4\%であり，LM 群の3.5\%に比較し，有意に多かっ た（p<0.05）。ま，上行結腸より口側を右側結腸， 横行結腸より肛門側を左側結腸として検討すると，右 側結腸が，H群およびLM 群でそれぞれ21.3\%, 7.0\% と $\mathrm{H}$ 群で有意に $(\mathrm{p}<0.05)$ 右側結腸に病変を有する症 例が多かった（表 3 ).
表 1 各群における症例の性別

\begin{tabular}{|c|c|c|c|c|}
\hline & \multicolumn{2}{|c|}{$H(>75$ y.o. $)$} & \multicolumn{2}{|c|}{$\operatorname{LM}(<49$ y.0. $)$} \\
\hline & No. & $\%$ & No. & $\%$ \\
\hline Female & 31 & 50.8 & 30 & 63.2 \\
\hline Male & 30 & 49.2 & 21 & 38.8 \\
\hline Total & 61 & 100.0 & 57 & 100.0 \\
\hline
\end{tabular}

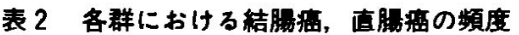

\begin{tabular}{lccccc}
\hline & \multicolumn{2}{c}{$H(>75$} & y.0. $)$ & & \multicolumn{2}{c}{$\operatorname{LM}(<49$ y.o. $)$} \\
\cline { 2 - 3 } \cline { 5 - 6 } & No. & $\%$ & & No. & $\%$ \\
\hline Colon & 30 & 49.2 & & 25 & 43.9 \\
Rectum & 31 & 50.8 & & 32 & 56.1 \\
\hline Total & 61 & 100.0 & 57 & 100.0 \\
\hline
\end{tabular}

\section{表3各群における病变占居部位}

\begin{tabular}{|c|c|c|c|c|c|}
\hline & & \multicolumn{2}{|c|}{ H (>75 y.0.) } & \multicolumn{2}{|c|}{$L M(<49$ y.0.) } \\
\hline & & No. & $\%$ & No. & $\%$ \\
\hline $\mathbf{V}$ & (Appendix) & 0 & 0.0 & 0 & 0.0 \\
\hline C & (Cecum) & 3 & 4.9 & 2 & 3.5 \\
\hline $\mathbf{A}$ & (Ascending colon) & 10 & $16.4^{*}$ & 2 & $3.5^{*}$ \\
\hline$T$ & (Transverse colon) & 1 & 1.6 & 3 & 5.3 \\
\hline D & (Descending colon) & 1 & 1.6 & 0 & 0.0 \\
\hline $\mathbf{s}$ & (Sigmoid colon) & 15 & 24.6 & 18 & 31.0 \\
\hline Rs & (Rectosigmoid) & 7 & 11.5 & 6 & 10.5 \\
\hline $\mathbf{R a}$ & (Upper rectum) & 3 & 4.9 & 10 & 17.5 \\
\hline $\mathbf{R b}$ & (Lower rectum) & 21 & 34.4 & 15 & 26.3 \\
\hline $\mathbf{P}$ & (Anal cenal) & 0 & 0.0 & 1 & 1.8 \\
\hline & Total & 61 & 100.0 & 57 & 100.0 \\
\hline
\end{tabular}

表 4 各群における切除率およひ治虑切除率

\begin{tabular}{lcccccc}
\hline & \multicolumn{2}{c}{$H(>75$ y.0.) } & & \multicolumn{2}{c}{ LM (<49 y.0.) } \\
\cline { 2 - 3 } \cline { 6 - 7 } & No. & $\%$ & & No. & $\%$ \\
\hline Curative & 51 & 68.9 & & 4 & 68.7 \\
Palliative & 10 & 13.5 & & 13 & 19.7 \\
No resection & 13 & 17.6 & & 9 & 13.7 \\
\hline Total & 74 & 100.0 & & 86 & 100.0 \\
\hline
\end{tabular}

\section{4）切除率およひ治瘾切除率（表 4)}

75歳以上の非切除症例を含めた全症例は, 74例あり, 原発巣を切除した切除率は，82.4\%であり，若・壮年 者群の $86.3 \%$ に比較し，やや低かったが，有意差は認 めなかった，さらに，治痣切除率は，H群， LM 群で それぞれ68.9\%，66.7\%と両群に有意差を認めなかっ た。た，手術による直接死亡率は，H群で 1 例 (1.6\%), LM 群で 1 例もなく, 有意差を認めなかった。

5）遠隔転移

それぞれの群で，P困子およびH因子につき検討し 
表 5 各群における遠隔転移

\begin{tabular}{|c|c|c|c|c|}
\hline & \multicolumn{2}{|c|}{$H(>75$ y.o.) } & \multicolumn{2}{|c|}{$\operatorname{LM}(<49$ y.0.) } \\
\hline & No. & $\%$ & No. & $\%$ \\
\hline \multicolumn{5}{|c|}{$\mathrm{H}$-factor } \\
\hline Ho & 59 & 98.3 & 54 & 94.7 \\
\hline$H_{1}$ & 1 & 1.7 & 2 & 3.5 \\
\hline $\mathrm{H}_{2}$ & 0 & 0.0 & 1 & 1.8 \\
\hline $\mathrm{Hs}_{3}$ & 0 & 0.0 & 1 & 1.8 \\
\hline \multicolumn{5}{|c|}{ P-factor } \\
\hline$P_{0}$ & 56 & 91.8 & 50 & 90.8 \\
\hline$P_{1}$ & 3 & 4.9 & 3 & 5.5 \\
\hline$P_{2}$ & 1 & 1.6 & 1 & 1.8 \\
\hline $\mathbf{P}_{3}$ & 1 & 1.6 & 1 & 1.8 \\
\hline
\end{tabular}

表 6 各群におけるリンパ節転移および ly, v 因子

\begin{tabular}{|c|c|c|c|c|}
\hline & \multicolumn{2}{|c|}{$H(>75$ y.0.) } & \multicolumn{2}{|c|}{$\operatorname{LM}\left(<4^{9}\right.$ y.o.) } \\
\hline & No. & $\%$ & No. & $\%$ \\
\hline \multicolumn{5}{|c|}{ Nodal status } \\
\hline no & 38 & $68.4^{*}$ & 27 & $47.4^{\circ}$ \\
\hline$n_{1}$ & 14 & 24.6 & 19 & 33.3 \\
\hline$n_{2}$ & 3 & 5.3 & 8 & 14.0 \\
\hline na & 1 & 1.8 & 1 & 1.8 \\
\hline$n_{4}$ & 0 & 0.0 & 2 & 3.5 \\
\hline \multicolumn{5}{|l|}{ ly factor } \\
\hline Iyo & 34 & 59.7 & 24 & 42.8 \\
\hline $\operatorname{ly}_{1}$ & 7 & 12.3 & 17 & 30.4 \\
\hline $\mathrm{ly}_{2}$ & 11 & 10.3 & 11 & 19.6 \\
\hline $1 y_{3}$ & 5 & 8.8 & 4 & 7.1 \\
\hline \multicolumn{5}{|l|}{$v$ factor } \\
\hline$v_{0}$ & 44 & 77.2 & 42 & 75.0 \\
\hline$v_{1}$ & 7 & 12.3 & 11 & 18.6 \\
\hline $\mathbf{v}_{\mathbf{2}}$ & 4 & 7.0 & 1 & 1.8 \\
\hline $\mathbf{v}_{\mathbf{3}}$ & 2 & 3.5 & 2 & 3.6 \\
\hline
\end{tabular}

た（表 5)．H 群で， $\mathrm{H}_{0} ， \mathrm{P}_{0}$ 症例はそれぞれ98.3\%， 91.8\%と, LM 群に比較し, やや遠隔転移を有する症例 は少なかったが, 推計学的には有意差を認めなかった。

6）リンパ節転移およU゙ly，v因子（表 6)

リンパ節転移陰性症例は，H群，LM 群でそれぞれ $68.4 \%, 47.4 \%$ と, $\mathrm{H}$ 群において多く, 推計学的に有 意差を認めた $\left(x^{2}=4.35, \mathrm{p}<0.05\right)$. 一方, ly 因子拈 よび $\mathrm{v}$ 因子では，陽性例が $\mathrm{H}$ 群において，やや多かっ たが，有意差は認めなかった。

\section{7) 臨床病期}

Astler-Coller 分類により，それぞれの臨床病期を表 7 に示した。A stageのみの比較では，有意に（p< 0.01) 高龄者群に多く,これに対し， $C_{2}$ stageは, 有 意に LM 群に多かった $\left(\chi_{2}=3.43, \mathrm{p}<0.05\right)$. したがっ て、リンパ節転移や遠隔転移を認めない、 $\mathrm{B}_{2}$ stage まて の症例は，H 群，LM 群でそれぞれ64.0\%, 42.1\%と， 高龄者群で有意に多かった（ $\left.x^{2}=4.80, \mathrm{p}<0.05\right)$.

8）壁深達度（表 8)

$\mathrm{m}$ 癌は $\mathrm{H}$ 群, LM 群で, それぞれ8.2\%,0\%と有意
表 7 各群における Astler-Coller 分類による䠦床病 期

\begin{tabular}{|c|c|c|c|c|}
\hline & \multicolumn{2}{|c|}{$H(>75$ y.o.) } & \multicolumn{2}{|c|}{ LM $(<\| 19 y, 0)}$. \\
\hline & No. & $\%$ & No. & $\%$ \\
\hline \multicolumn{5}{|c|}{ Astler-Coller } \\
\hline A & 11 & $18.0^{*}$ & 1 & $1.8^{*}$ \\
\hline $\mathbf{B}_{1}$ & 9 & 14.8 & 5 & 8.8 \\
\hline $\mathbf{B}_{2}$ & 19 & 31.1 & 18 & 31.0 \\
\hline$c_{1}$ & 3 & 4.9 & 4 & 7.0 \\
\hline $\mathrm{C}_{2}$ & 13 & $21.3^{t}$ & 22 & 38.64 \\
\hline D & 0 & 9.8 & 7 & 12.3 \\
\hline Total & 61 & 100.8 & 57 & 100.0 \\
\hline
\end{tabular}

表 8 各群における壁深達度

\begin{tabular}{|c|c|c|c|c|}
\hline & \multicolumn{2}{|c|}{$\mathrm{H}(>75$ y.0.) } & \multicolumn{2}{|c|}{ LM $(<49$ y.0.) } \\
\hline & No. & $\%$ & No. & $\%$ \\
\hline$\vec{m}$ & 5 & $8.2^{*} 7$ & 0 & $0.0^{\circ} 7$ \\
\hline $\mathbf{s m}$ & 4 & $6.6-1$ & 1 & $1.8-1$ \\
\hline pm & 14 & $23.0 \mathrm{~J}$ & 7 & $12.3]$ \\
\hline$s s\left(a_{1}\right)$ & 21 & 34.4 & 28 & 49.1 \\
\hline$\$\left(a_{2}\right)$ & 12 & 19.7 & 13 & 22.8 \\
\hline si & 5 & 8.2 & 8 & 14.4 \\
\hline Total & 61 & 100.0 & 57 & 100.0 \\
\hline
\end{tabular}

表 9 各群における病理組織型

\begin{tabular}{|c|c|c|c|c|}
\hline & \multicolumn{2}{|c|}{ H (>75 y.0.) } & \multicolumn{2}{|c|}{ LM (<19 y.o.) } \\
\hline & No. & $\%$ & No. & $\%$ \\
\hline well diff. adenoce. & 34 & 55.77 & 23 & 40.47 \\
\hline moderately diff. adenoca. & 24 & $39.3]^{3}$ & 21 & (2.1 \\
\hline poorly diff, adenoce. & 2 & 0.0 & 3 & 5.3 \\
\hline mucinous ca. & 1 & $1.6^{*}$ & 7 & $12.3^{\circ}$ \\
\hline squamous cell ca. & 0 & 0.0 & 0 & 0.0 \\
\hline others & 0 & 0.0 & 0 & 0.0 \\
\hline Total & 61 & 100.0 & 57 & 100.0 \\
\hline
\end{tabular}

に高龄者に多く，また，壁深達度が $\mathrm{pm}$ までの症例が， $\mathrm{H}$ 群，LM 群でそれぞれ37.8\%，14.1\%であり推計学 的に有意差を認めた $\left(x^{2}=7.35, \mathrm{p}<0.01\right)$. $\mathrm{m}$ 癌のみ の比較であ有意差を認めた $(\mathrm{p}<0.05)$. したがって, 高龄者群では, 比較的壁深達度の浅い症例が多かった。

9）組織型（表 9)

LM 群において, mucinous carcinoma が 7 例 $(12.3 \%)$ と $\mathrm{H}$ 群に比較し, 推計学的に有意に多くみら れた $(\mathrm{p}<0.05)$.さらに，H群では，分化型腺癌が全 体の95.0\%と LM 群に比較し，有意に多かった（ $p<$ 0.05).

10）遠隔成績 


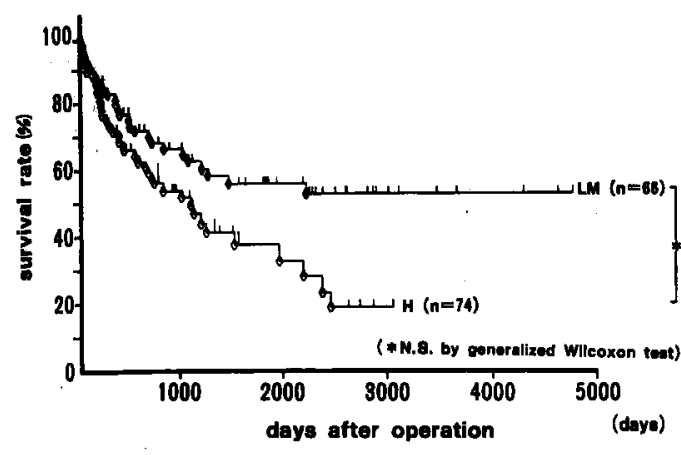

$\mathbf{a}$ ；非切除症例を含めた全症例

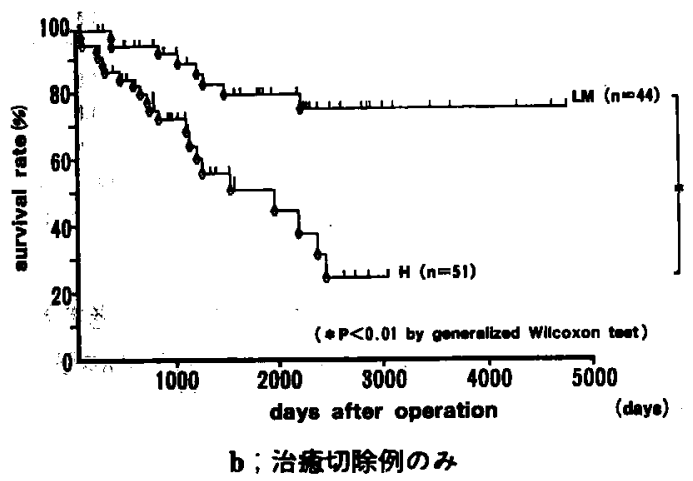

图 3 H群、LM群における采程生存率の比較 (Kaplan-Meier 法)

\section{a) 非切除を含めた全症例での比较}

非切除となった症例を含めた75歳以上の症例74例 と，49墄以下の症例66例の遠隔成績を，老衰，他病死 を含めて比較した（図 3a)．49歳以下の症例の累積 5, $7 ， 10$ 年生存家はそれぞれ63.8\%，60.2\%，60.2\%と 比較的良好であったのに対し，75歳以上の症例では， 5，7生率はそれぞれ $44.7 \% ， 22.3 \%$ と不良であった。

b）治空切除例における比筊

治澺切除例のみで, H 群 (51例) と LM 群 (44例) を比較した（图 3b).H 群の 5，7生率はそれぞれ 51.8\%, 25.9\%であり，一方，LM 群の 5，7，10生率 は80.2\%，75.7\%，75.7\%であった。さらに老哀，他 病死を除いた治掼切除例の累積生存率を検討した（図 4). $\mathrm{H}$ 群の 5 生率，7生率はそれぞれ85.7\%，68.5\% であり, LM 群では 5 生率, 7 生率はともに81.5\%であ り，両群に有意差を認めなかった。

c) 病期別の比較

Astler-Coller の分類別の老衰，他病死を除いた治癁 切除例のみの累積生存率を両群で比較した。いずれの stage でも両群に有意差を認めず，ちなみに, stage $\mathrm{B}_{1}$ では, H 群, LM 群の 7 生率は, それぞれ100\%, 66.7\% (図 5a), stage $B_{2}$ では, $77.4 \%, 66.7 \%$ (図 5b), stage $\mathrm{C}_{2}$ では78.8\%，71.4\%（図 5c）であった。

11) 再発死亡例お $よ ひ$ 再発部位

遠隔成績を，癌の再発といら面からる検討するため， 再発死亡例についても検討した．治瘦切除例のうち， 再発死亡例は $\mathrm{H}$ 群で 4 例 $(7.8 \%), \mathrm{LM}$ 群で 6 例 (13.6\%)であり，ややLM群が高かったが，有意差は 認めなかった。ささらに再発症例の病変占居部位にも差

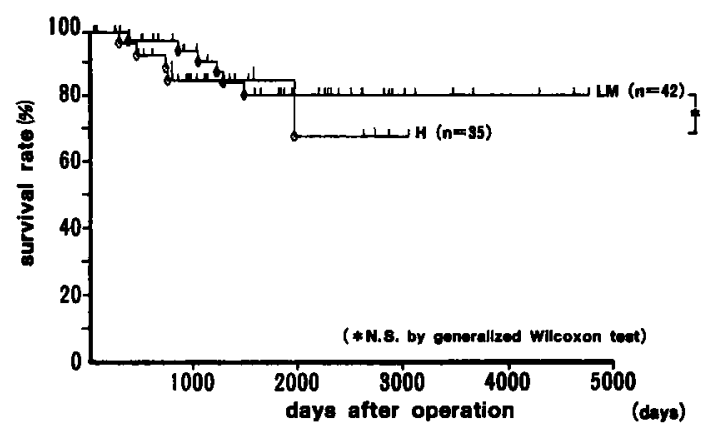

图 4 他病死例を除いた切除例における H 群, LM 群 の果䅡生存率の比较（Kaplan-Meier 法）

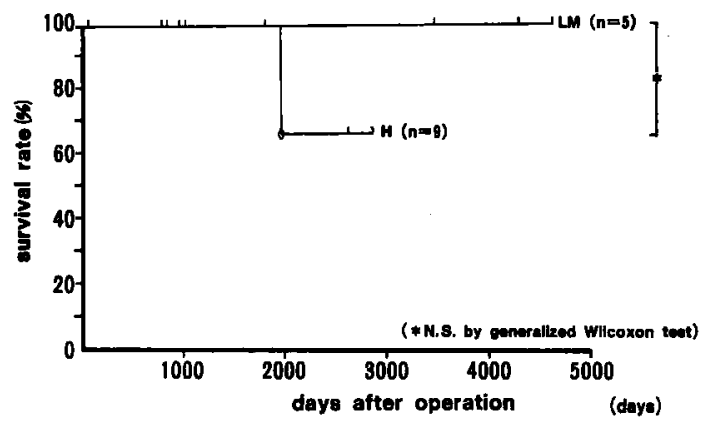

a)

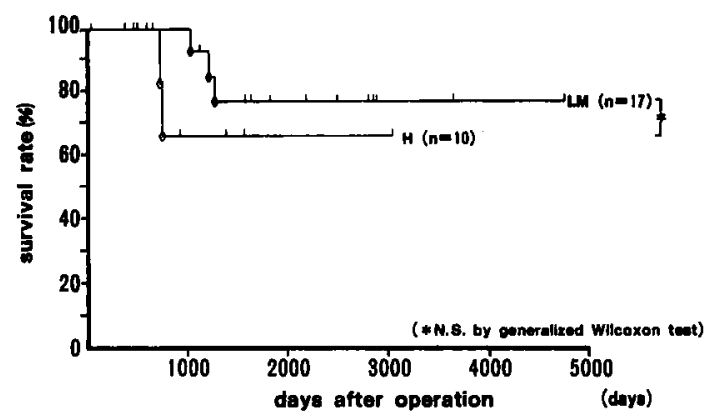

b) 


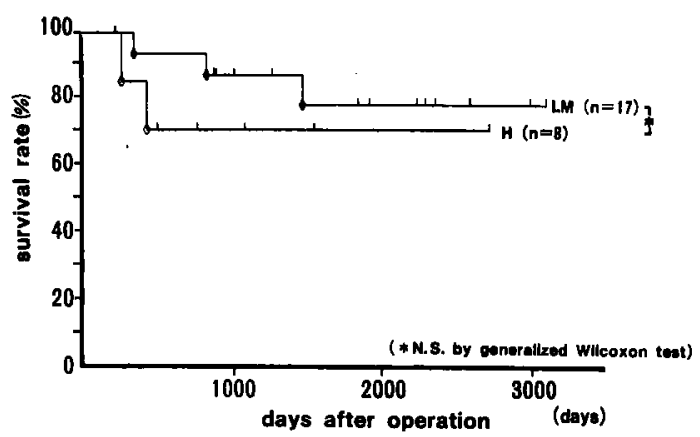

c)

図 5 他病死例を除いたにおける果積生存率の比较 (Kaplan-Meier 法)

$\mathrm{a}$; Astler-Coller $\mathrm{B}_{2}$ stage 症例の文, b; AstlerColler $\mathrm{B}_{2}$ stage 症例のみ, $\mathrm{c}$; Astler-Coller $\mathrm{C}_{2}$ stage 症例のみ

表10 再発死亡症例の病变占居部位

\begin{tabular}{|c|c|c|c|c|}
\hline & \multicolumn{2}{|c|}{$\mathrm{H}(>75$ y.o.) } & \multicolumn{2}{|c|}{ LM $(<49$ y.0.) } \\
\hline & No. & $\%$ & No. & $\%$ \\
\hline \multicolumn{5}{|l|}{$\mathbf{v}$} \\
\hline \multicolumn{5}{|c|}{2.0} \\
\hline \multirow{2}{*}{\multicolumn{5}{|c|}{$\begin{array}{l}T \\
D\end{array}$}} \\
\hline & & & & \\
\hline \multicolumn{5}{|c|}{2.0} \\
\hline Rs & & & 1 & 2.3 \\
\hline $\mathbf{R a}$ & & & 1 & 2.3 \\
\hline $\mathbf{R b}$ & 2 & 3.9 & 3 & B.8 \\
\hline $\mathbf{P}$ & & & & \\
\hline Total & 4 & 7.8 & 6 & 13.6 \\
\hline
\end{tabular}

表11 再発死亡症例の術後生存期間

\begin{tabular}{lcc}
\hline & $H(>74$ y.o. $)$ & $L M(<19$ y.0. $)$ \\
\hline mean survival period(month) & $14.8^{*}$ & $34.0^{*}$ \\
$\max$. & 9 & 12 \\
$\min$. & 24 & 48 \\
\hline$* P<0.05$ by i-test & &
\end{tabular}

1970-1960. $\mathrm{HCH}$

を認めなかった(表10)。をた，再発死亡までの期間は $\mathrm{H}$ 群で14.8カ月, LM 群で34.0カ月と， H 群で有意に （p<0.05）短かった（表11）。再発形式を表12に示した が，それぞれの部位において，両群に有意差を認めな かった。

\section{2）重複癌および多発癌の検討}

他藏器の重複癌は，H群で5例 $(8.2 \%)$ ，LM 群で 1 例 $(1.8 \%$ ) に見られた。一方，多発癌は H 群，LM 群でそれぞれ 2 例 (3.3\%)，1 例 (1.8\%) にみられ， いずれる同時性多発癌であった（表13）.
表12 再発死亡症例の再発部位

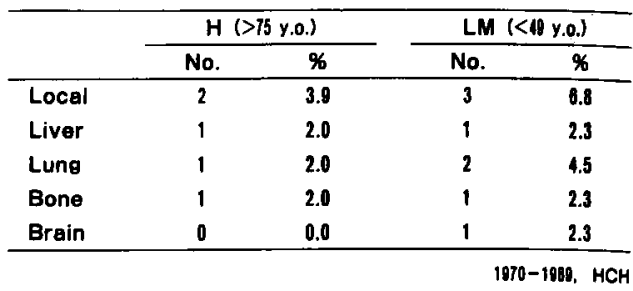

表13各群における重複癌および多発重

\begin{tabular}{ccccccc}
\hline & \multicolumn{2}{c}{$\mathrm{H}(>75$ y.0.) } & & \multicolumn{2}{c}{ LM $(<40$ y.0.) } \\
\cline { 2 - 3 } \cline { 5 - 6 } & No. & $\%$ & & No. & $\%$ \\
\hline Double cancers & 5 & 8.2 & & 1 & 1.8 \\
& & & & & \\
Multiple cencers & 2 & 3.3 & & 1 & 1.8 \\
synchronous & 2 & 3.3 & & 1 & 1.8 \\
metachronous & 0 & 0.0 & & 0 & 0.0 \\
\hline
\end{tabular}

考察

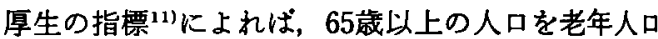
と規定し，1988年には老年人口は全体の $10.9 \%$ を占め， 依然として增加傾向を示しているとい5，今回，高龄 者大腸癌の臨床的病理学的特徽をより明確にする目的 で，あえて第27回大腸癌研究会によるマンヶート調查 と同様に，高齢者大腸癌を75歳以上の症例とし，49藏 以下の若・壮年者症例とを比較検討した。

病变占居部位では，H 群で上行結腸に $16.4 \%$ LM 群に比較し有意に多く，従って，結果的に右側結腸に $21.3 \%$ 之有意に多かった，全国大腸癌登録調查報告 ${ }^{12}$ では，この傾向は認められていないか， Richards ${ }^{13)}$,

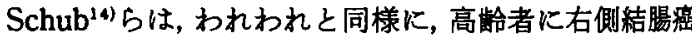
が多い傾向を指摘して括り，さらに，最近では大腸癌 の局在が右側結腸に偏位してきているとの報告るみら れる ${ }^{15)}$ 。これは大腸癌発生の原因として指摘されてい る胆汁酸成分である。 $7 \alpha$-dehydroxylated bile salt $と$ の関連 ${ }^{16)}$ 考えられ，興味潹い点である。

一方, 切除率扣よび治瘦切除率は 49 歳以下の症例と 変わらず手術が行われて招り，さらに，直接死亡率は， $\mathrm{H}$ 群で 1 例 (1.6\%)，LM 群で 1 例むみられず， $\mathrm{H}$ 群 でもきわめて良好な結果であった。これは後です速べ るが，高龄者症例の risk factor す考えれば, 比較的病 期が早い症例が多いことも関連しているものと考克ら れる。初回手術時に $\mathrm{H}(+)$ ，あるいは $\mathrm{P}(+)$ であった 症例は有意差はなかったものの，やゃ高齢者では少な い傾向を示したが，従来の報告は，一定の傾向は示さ 
れていない。これに対して、リンパ節転移は，H群で 陰性症例が68.4\%と LM 群に比較して有意に多かっ た。この結果は，リンパ節の郭清度といらバイフスが 入る可能性す考えられるが，今回検討した症例は $\mathrm{m}$ 癌 以外㤝いずれる $\mathrm{R}_{1}$ 以上のリンパ節郭清をともなった 手術を施行した症例であり，その可能性はないすのと 考えられ，高龄者群で明らかにリンパ節転移が少ない 症例か有意に多かったものと考学られる。八田ら ${ }^{17}$ は, 大腸癌周辺のリンパ球浸潤が所属りンハハ節転移に関与 していると報告し，高齢者では局所のリンパ球漫潤が 少ないとしており，今回の検討ではこの報告と同様の 結果が得られた。 また，壁深達度についてる高龄者で $\mathrm{pm}$ までの比較的深達度の浅い症例が37.7\% と若・壮 年者と比較し, 有意に多く, 従来の報告と同様であっ た。従って，臨床病期では，リンパ節転移や遠隔転移 のないAstler-Coller 分頑にて $B_{2}$ での症例が，49歳 以下の症例に比較し有意に多い結果となった。組織型 では，LM 群で粘液癌が12.3\%と $\mathrm{H}$ 群に比較し，有意 に多かったために, 分化型腺癌が $\mathrm{H}$ 群で有意に多いと いら結果になった，これは，大腸の粘液癌が若年者に 多いことは以前から知られることであり，最近でる報

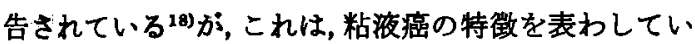
るすのと思われる。

これらの臨床病理学的検討の結果より，75歳以上の 高龄者症例といえどす，従来より指摘されている全身 的な risk factorに十分留意して手術を施行すれば良 好な成績が得られると考えられる。

一方, 高龄者大腸癌は, 多発癌や重複癌が多いとい ら報告19220)が見られるが，今回の検討でも壮年者群に 比校し有意差は認めないすのの，その頻度は高かった。 このことは発癌といら面からは，太田ら ${ }^{21)}$ の指摘する ことく，大腸癌の発生は，年龄依存性が強いと考光ら れ，ウイルス依存性のある種の癌や，ホルモン依存性 の強い乳癌，遺伝性の強い家族性大腸ボリポーシスに おける癌などとは明らかに性格が異なるるのと考克ら れる。一方，癌の発育，進展といら概念到からみると， 遠隔転移，リンハ節転移は少なく，比較的病期の早い あのが多く，やはり，従来より指摘されている高齢者 の疾の特徽である低成長性，限局性といった性格を示 唆しているすのと考党られる，従って，高路者大腸癌 の予後は，1）癌の発生，2）癌の発育，進展といら二 つの側面から考える必要があり， 今後，DNA ploidly pattern ${ }^{23241)}$ 中 Tumor doubling timeなどの癌の発 育，進展の指標となる新しいマーカーの検索む必要で
あると考光られる。

最後に遠隔成績についてであるが，今回の検討で示 したごとく，高龄者症例に老衰や他病死が多いために， これらを含めた累積生存率の検討のみでは，より明確 な高龄者大腸癌の予後を示すデータは得られないと思 われた，従って，現在までの高齢者大腸癌の遠隔成績 の報告は，対象群より良好であるという報告726) と不 良であるといら相反する報告3)53がある. Payne ら ${ }^{26)}$ 75歳以上の高踰者大腸癌310例の報告では, 他病死を含 めた累積 5 年生存率は $30 \%$ \%すり，対象群に比較し， 有意に不良であるとしているが，他病死を除いた cancer-related survival は，50\%であったと報告して いる. 一方，わが国の全国調査直腸癌治瘁切除例で 5 生率78.9\%であり，比較白良好な成績が得られている。 今回の检討では，高龄者治旗切除例で，5生率， 7 生 率はそれぞれ，51.8\%，25.9\%であり，49歳以下の症 例と比較し，有意に不良であった。そこで，他病死， 他癌死，老衰などによる死亡を除いた累積生存率を算 出したところ，高龄者大晹癌治癁切除例で，5生率， 7 生率はそれぞれ高龄者群で85.7\%，68.5\%で，若・ 壮年者群では 5 生率, 7 生率ともに81.6\%であり，や や高龄者の方が不良であったが有意差を認めなかっ た. したがって，高齢者の症例の方が stage が若・壮年 者に比較し，早期のむのが多いことを考え合わせると 高龄者症例の予後はやや不良であると考えられる。一 方, 再発死亡率といら面から検討すると，高龄者群の 方が再発死亡率は低かったが，高龄者大腸癌治空切除 例のらち，現在までに20例の死亡症例があり，そのう ち，16例（75\%）までが老衰あるいは他病死（他癌に よる癌死を含む）であった．したがって，長期の遠隔 成績を比較する場合は縤密には，いわゆる cancerrelated survival を参考にすべきと考えられ，今回の検 討でも，他病死，老衰を除いた生存率にて比較検討を 行った，大腸癌では今後，より長期の遠隔成績を検討 するよらになると思われ，統一した予後の分析法が必 要になると思われる。

以上の結果より, 高齡者大腸癌症例でる積極的な根 治性をめざした外科的治療を施行されるべきと考古ら れ，それにより若・壮年者とはとんど変わらない成續 が得られるものと考光られる。

\section{まとめ}

大腸癌切除症例の ちち，75歳以上の高齢者 61 例につ き，49歳以下の症例57例と比較することにより，臨床 病理および遠隔成績より検討した結果, 次の上うな結 
論を得た。

1）病変占居部位は右側結腸に全体の $21.3 \%$ 有意 に多かった。

2）高齢者群の切除率は92.4\%, 治空切除率 $68.9 \%$ で 壮年者群と有意差を認めなかった。

3） $\mathrm{P}$ 因子， $\mathrm{H}$ 因子には両群に有意差を認めなかっ た。

4）リンパ節転移陰性例は高龄者群で $68.4 \%$ と壮年 者群の $47.4 \%$ に比較し有意に多かった.

5）病期では，高龄者群で Astler-Coller A 症例が $27.9 \%$ と有意に多く，また， $\mathrm{C}_{2}$ 症例が，有意に少なかっ た。遠隔転移やリンバ節転移のない Astler-Coller $B_{2}$ までの症例が $64.0 \%$ と有意に多かった。

6）組織型では，分化型腺癌が全体の95.0\%と有意に 多く, 壮年者群で, 粘液癌が $12.3 \%$ と高龄者群の $1.6 \%$ に比較して有意に多かった。

7）壁深達度です高龄者群で pmまでの症例が $37.8 \%$ と壮年者群で $14.1 \%$ に比較し有意に多かった。

8）老哀，他病死を含めた 7 年生存率は，高制者群， 壮年者群でそれぞれ $60.2 \% ， 22.3 \%$ と高跲者群で有意 に不良であったが，老衰，他病死を除いた 7 生率はそ れぞれ $81.6 \% ， 68.5 \%$ とやや高龄者の方が不良であっ たが，有意差を認めなかった。

9）再発死亡率は, 高龄者群, 若・壮年者群でそれそ れ7.8\%，13.6\%で高㱓者の方が低率であったが，再発 死亡までの期間は平均 14.8 カ月, 34.0 カ月之高齢者の 方が有意に短かった。

\section{文 献}

1）浅越辰男, 青木明人，岡芹繁夫他：当院における原 発性大腸癌症例の臨床的分析と治療の問題点, 日 消外会誌 $17: 2208-2213,1984$

2）高相 進, 竹村克二, 金子度虎他：高龄者大腸癌の 臨床病理学的検討, 日臨外医会誌 $47: 188-194$, 1986

3）坂本一次，奥野匡有，池原照幸他：高年者大腸癌の 検討. 若・壮年者との対比, 外科治療 54：627 $-633,1986$

4) 神田 裕, 蜂須賀喜多男, 山口晃弘他：高龄者大腸 癌の臨床的特徽と risk factor, 日消外会誌 19 : 2121-2124, 1986

5）森田隆幸, 橋爪 正, 今 充他：高龄者大腸癌症 例の検討，日消外会誌 $20: 2431-2434,1987$

6）関根毅，鈴木章一, 須田䔨夫：高龄者直腸癌治癁 切除例の検討一臨床病理学的成綪と遠隔成績を中
心に一，日消外会誌 $22: 819-825,1989$

7）安富正幸, 松田泰次, 相良憲幸他：高龄者大腸癌手 術の問題点とその対策, 外科治療 $58: 441-448$, 1988

8）大腸癌研究会編：臨床・病理. 大腸癌取扱い規約. 改訂第 3 版, 東京, 金原出版, 1985

9) Astler VB, Coller FA: The prognostic significance of direct extension of carcinoma of colon and rectum. Ann Surg 139 : 846-851, 1954

10) Kaplan E, Meier P: Nonparametric estima. tion from incomplete observations. J Am Stat Assoc 53 : 457-481, 1958

11) 厚生統計協会編：厚生の指標. 第35巻, 第 9 号(躁 時増刊一国民衛生の動向), p40-41, 財団法人, 厚 生統計協会発行, 東京, 1988

12）大腸癌研究会登録委員会：全国大腸癌登録調榃報 告. 第 2 号, 大腸癌研究会, 1987

13) Richards PC: Colorectal cancer in the elderly. Front Radiat Ther Onc 20 : 139-142, 1986

14) Schub R, Steinheber FU : Rightward shift of colon cancer. J Clin Gastroenterol $8: 630-634$, 1986

15) Rosato FE, Marks G: Changing site distribution patterns of colorectal cancer at Thomas Jefferson University Hospital. Dis Colon Rectum $26: 393-398,1981$

16) van der Werf $S D$, Huijbregt $A W$, Lamers $H L$, et al: Age dependent difference in human bile acid metabolism and 7 alfa-dehydroxylation. Eur J Clin Invest $11: 425-431,1981$

17）八田昌樹, 泉本源太郎, 安富正幸他：癌の病理組珷 学的性状と組䋍反応からみた大腸癌のリンパ節较 移に関する研究, 日本大腸肛門病会誌 $40: 1-7$, 1987

18）佐々木一晃，简井 完，秋山守文他：大腸粘液澏の 検討, 日消外会誌 $22: 814-818,1989$

19）今西 築, 多淵芳樹, 中江史朗他：大腸多発澏の背 景因子ならびに臨床病理学的特徽に関する検討, とくに多発癌之単発癌の相違について, 日消外会 誌 $17: 1579-1586,1984$

20）棈爪正, 森田隆幸，山中祐治他：大腸多発癌上重 複癌症例の検討, 日消外会誌 22：1102-1107， 1989

21)太田和夫：高齢者の癌の特徵, 癌の化療 13 : $3105-3108,1988$

22) Noewl PC: The clonal evolution of tumor cell 
populations. Science $194: 23-28,1976$

23) Drings VM, Mattern P, Sonka J, et al: Prognostic significance of DNA patterns and resistance predictive test in non-small cell carcinoma. Cancer 56 : 1396-1403, 1985

24) Hedley W, Rugg CA, Gelber RD, et al : Association of DNA index and S-phase fraction with prognosis of nodes positive early breast cancer.
Cancer Res $47: 4729-4735,1987$

25）森谷宜皓, 小山靖夫：高齢者大晹癌一臨床病理学 的特徵と外科治療上の問題点について一，老人科 診療 3:275一281, 1983

26) Payne JE, Chapius PH, Pheils MT, et al: Surgery for large bowel cancer in people aged 75 years and older. Dis Colon Rectum 29:733 $-737,1986$

\title{
CLINICOPATHOLOGICAL FEATURE AND PROGNOSIS OF AGED PATIENTS OVER 75 YEARS WITH COLORECTAL CANCER -A COMPARISON WITH PATIENTS UNDER 50 YEARS-
}

\author{
Yoichi SAKURAI, Akahito AOKI, Shigeo OKAZERI, Toshio KANAI, Hideo SHIMADA, \\ Takako SUNAGA, Yoshiro SAIKAWA and Ryuichi NAKAYAMA \\ Department of Surgery, Hiratsuka City Hospital
}

Among 327 patients operated on for colorectal carcinoma in Hiratsuka City Hospital during 1970-1989, 61 patients of 75 years and upward ( $\mathrm{H}$ group) were selected and compared for the clinicopathologic details and prognosis with 57 patients under 50 years (LM group). There were no significant difference between these two groups in the rates of resection, curative resection and operative death. A significantly higher frequency of rightsided tumors was noted in $\mathrm{H}$ group. No significant difference was observed in the frequency of patients having distant metastases. Proportion of patients with negative regional lymph node metastasis in $\mathrm{H}$ group was $68.4 \%$, whereas $47.4 \%$ in the LM group with a significant difference $(p<0.05)$. Proportion of each clinicopathological stages due to Astler-Coller showed a significant difference between these two groups. The proportion of patients who were in stage $\mathrm{A}$ was $18.0 \%$ in $\mathrm{H}$ group, whereas $1.8 \%$ in $\mathrm{LM}$ group, with a significant difference $(\mathrm{p}<0.05)$.

Proportion of mucinous adenocarcinoma in $\mathrm{H}$ or LM group was $1.6 \%$ or $12.3 \%$ respectively, with a significant difference $(p<0.05)$. Cumulative 7-year survival rates were $22.3 \%$ in $\mathrm{H}$ and $60.2 \%$ in LM group, with a significant difference $(p<0.01)$. On the other hand, colorectal cancer-related 7-year survival rates in the $\mathrm{H}$ and LM groups were $68.5 \%$ and $81.6 \%$ respectively, of which difference was not significant. It is concluded that there is obvious clinicopathologic difference between elderly and relatively younger patients, and that the operative indication for colorectal cancer in the elderly is justifiable and should not be restricted only by a risk factor of age. 